\title{
INFLUENCE OF CYPROTERONE ACETATE DURING PREGNANCY ON THE SEXUAL BEHAVIOUR OF MALE GUINEA-PIGS
}

\author{
V. ETZEL, B. SGHENGK AND F. NEUMANN \\ Department of Endocrinpharmacology, Research Laboratories, \\ Schering $A G$, Berlin/Bergkamen, Germany*
}

(Received 18th April 1973)

\begin{abstract}
Summary. Female guinea-pigs were treated with $50 \mathrm{mg}$ cyproterone acetate (CA) $/ \mathrm{kg}$ body weight/day from the 30 th to the 45 th day of pregnancy. Fifteen of their male offspring were reared and their sexual behaviour was observed. Eleven of the test males showed no signs of male sexual behaviour when in contact with females in oestrus. All the masculine behaviour patterns were observable in only one test male. When in contact with normal male animals, the test males showed signs of feminine sexual behaviour, but spontaneous lordosis reactions were not observed.

After castration and treatment with $50 \mu \mathrm{g}$ testosterone propionate per day, the male offspring of sows which had received CA treatment showed reduced masculine sexual behaviour by comparison with control animals which had undergone the same treatment.

After treatment with $3 \mu \mathrm{g}$ oestradiol benzoate and $0.2 \mathrm{mg}$ progesterone, significantly longer lordosis reactions were observed in the test males than in the control males which had received the same treatment, but the reactions were significantly shorter than in ovariectomized females treated with oestradiol benzoate and progesterone.
\end{abstract}

\section{INTRODUCTION}

Androgens influence the differentiation of the hypothalamic centres which are responsible for sexual behaviour. In rats, the differentiation occurs postnatally whereas, in the guinea-pig, it takes place between the 30th and 35th day of the fetal stage (Goy, Bridson \& Young, 1964). If female guinea-pigs are subjected to the influence of androgens during this differentiation stage, i.e. their mothers are given an androgen, they show signs of masculine sexual behaviour as adults (Avery, 1925; Young, Dempsey \& Myers, 1935; Dantchakoff, 1938a, b; Young, Dempsey, Hagquist \& Boling, 1939). If these animals are spayed when they are sexually mature, and substitution treatment with oestradiol benzoate and progesterone or testosterone propionate is given, an intensification of the male pattern of sexual behaviour is observed, while the feminine be-

\footnotetext{
* Postal address: 1 Berlin 65, Müllerstrasse 170-172, West Germany.
} 
haviour-lordosis reaction-is suppressed (Phoenix, Goy, Gerall \& Young, 1959; Goy, Bridson \& Young, 1961).

This article examines the influence of cyproterone acetate (CA) in pregnant guinea-pigs on the sexual behaviour of male offspring. While this work was in progress, the paper of Goldfoot, Resko \& Goy (1971) was published. These authors treated female guinea-pigs with 20 or $40 \mathrm{mg} \mathrm{CA} /$ animal/day from the 28 th to the 58th day of pregnancy. These doses are similar to the doses used in our experiment. Goldfoot et al. (1971) observed no reduction of masculine sexual behaviour of the male offspring as compared with controls. Although reduction of intromission and ejaculation was noted, these findings were not interpreted as an effect of CA on the differentiation of the hypothalamus because a malformed penis could also be responsible for this effect. No behavioural feminization of CA-treated males was observed. After castration and treatment with $3 \mu \mathrm{g}$ oestradiol benzoate and $0.4 \mathrm{mg}$ progesterone, these males displayed no lordosis reaction.

\section{MATERIALS AND METHODS}

Five-month-old female guinea-pigs in oestrus were mated. The day of insemination was determined by the presence of vaginal spermatozoa. During pregnancy, the females received daily intramuscular injections of CA $(50 \mathrm{mg} /$ $\mathrm{kg}$ ) from the 30th to the 45th day. The anti-androgen was dissolved in a mixture of benzyl benzoate and castor oil in the ratio of $1: 10$. A control group received comparable injections of the solvent.

Fifteen male offspring of the drug-treated females and fifteen male control offspring were examined at the age of 5 months, using four basic tests: (A) signs of masculine or feminine sexual behaviour when placed with untreated males; (B) signs of masculine sexual behaviour when placed with females in spontaneous oestrus; (C) five of the males prenatally exposed to CA (CA-males) were castrated after tests A and B had been carried out. Four weeks later, daily injections of testosterone propionate $(0.5 \mathrm{mg} / \mathrm{kg})$ were given and their sexual behaviour with females in oestrus was observed, at weekly intervals, for a further 4 weeks; (D) four weeks after the last application of testosterone propionate, the animals used in ' $\mathrm{C}$ ' received an intramuscular injection of $3 \mu \mathrm{g}$ oestradiol benzoate, followed $36 \mathrm{hr}$ later by $0.2 \mathrm{mg}$ progesterone. Tests were then made to see if signs of feminine sexual behaviour appeared in the presence of normal males. The occurrence and duration of the lordosis reaction in the treated male were noted.

In order to assess masculine behavioural responses, the test males were placed with females in oestrus. The occurrence and duration of the five behavioural patterns, 'nibbling', 'nuzzling', 'mounting', 'intromission' and 'ejaculation', were observed within a 10-min test period. The grade of masculine behaviour was determined with the help of a points system which was developed by Young \& Grunt (1951). The maximum score (20) applied to an animal which ejaculated within the first 15 sec. Males which showed no signs of masculine behaviour received no points. 


\section{RESULTS}

Test $A$

In this test, the behaviour of fifteen males exposed to CA was observed when they were placed with untreated adult males. The latter immediately pursued the test males, which displayed the running activity of normal females. In $80 \%$ of the test males, this activity ended after a few seconds, in the remainder, after 2 to $3 \mathrm{~min}$. All the untreated males started 'nuzzling', which was accepted by the test males. Subsequent 'mounting' was either accepted by the latter or attempts were made to push the untreated males away with the rear legs, a typical reaction for females not in oestrus. The 'lordosis' reaction could not be observed in any of the prenatally treated males. On the other hand, when two control males were placed together they behaved in a typically aggressive manner.

\section{Test $B$}

When placed one at a time with a female in spontaneous oestrus, eleven of the fifteen test males showed none of the typical masculine behaviour patterns during the whole of the 10-min observation period. In three animals, masculine behaviour patterns such as 'nibbling', 'nuzzling' and 'mounting' were observed. Only one showed all the behavioural patterns, including intromission and ejaculation. Immediately after ejaculation, this male was placed with a control male. The test male accepted mounting by the control male.

When control males were placed with females in spontaneous oestrus, all five masculine behaviour patterns could be observed in the first $5 \mathrm{~min}$, and an average of $13 \cdot 2$ points was achieved.

Test $C$

Five test males were selected on the basis of feminine sexual behaviour in the presence of control males and absence of masculine signs when placed with females in oestrus. These animals and five controls were castrated. Four weeks later, they were injected daily with testosterone propionate $(0.5 \mathrm{mg} / \mathrm{kg})$. After 8 days of treatment, typical masculine sexual behaviour was observed in all the animals in the presence of females in oestrus. The control males attained an average of 8.2 points and the test males an average of 5.0 points (Text-fig. 1). In the latter group, the mounting frequency was not so great, but the lower patterns of sexual behaviour like 'nibbling' and 'nuzzling' were more common and lasted longer. When placed with intact control males, they also showed signs of typical aggressive behaviour among themselves.

\section{Test $D$}

Four weeks after the conclusion of the testosterone propionate treatment in test ' $\mathrm{C}$ ', the CA-males received $3 \mu \mathrm{g}$ oestradiol benzoate and $36 \mathrm{hr}$ later, an injection of $0.2 \mathrm{mg}$ progesterone. The castrated control males used in test ' $\mathrm{C}$ ', and ovariectomized females which were also given oestradiol benzoate and progesterone, served as control animals.

With respect to the time of occurrence of behaviour typical of oestrus, there 
was no significant difference between the three groups. The duration of such behaviour, however, was significantly longer in the ovariectomized females than in both groups of males. Within each group, there were great individual differences in the length of the 'oestrous' phase and significant differences between all three groups with respect to the duration of the lordosis reaction.

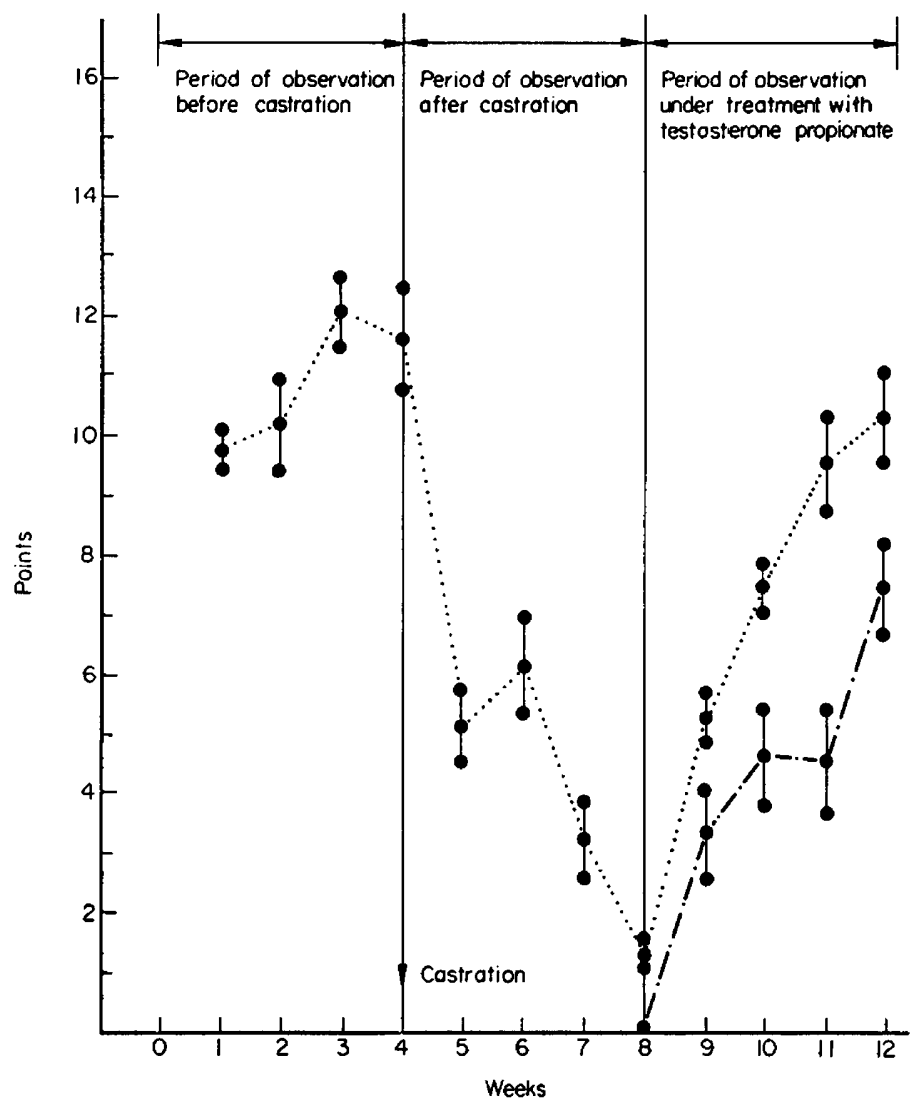

TEXT-FIG. 1. The influence of castration and treatment with testosterone propionate $(0.5 \mathrm{mg} / \mathrm{kg} / \mathrm{day})$ on the sexual behaviour of male guinea-pigs. $-\cdot-\cdot-=$ exposed to cyproterone acetate in utero $; . \ldots \ldots=$ control males. The vertical lines represent the standard deviation from mean value.

The lordosis reaction lasted longest in the oestrogen-treated ovariectomized females, next came the group of CA-males and the shortest time was observed in the control castrated males. Within each group, significant individual differences were recorded (see Tables 1 and 2).

\section{DISGUSSION}

After the treatment of pregnant guinea-pigs with the anti-androgen, cyproterone acetate, from the 30th to the 45 th day of pregnancy, no signs of masculine sexual behaviour could be observed in $73 \%$ of the male offspring. On the other 
Table 1. The effect of treatment with oestradiol benzoate and progesterone on sexual behaviour and the development of oestrus in ovariectomized guinea-pigs, males whose mothers had been treated with cyproterone acetate during pregnancy, and castrated control males

\begin{tabular}{c|c|c|c|c}
\hline \multicolumn{1}{c|}{$\begin{array}{c}\text { Group of animals } \\
\begin{array}{c}\text { No. of } \\
\text { animals }\end{array}\end{array}$} & $\begin{array}{c}\text { Occurrence of } \\
\text { oestrous' behaviour } \\
\text { after injection } \\
\text { of progesterone } \\
\text { (hr) }\end{array}$ & $\begin{array}{c}\text { Mean } \\
\text { Duration } \\
\text { of 'oestrous' } \\
\text { behaviour } \\
\text { (hr) }\end{array}$ & $\begin{array}{c}\text { duration of } \\
\text { lordosis } \\
\text { reaction } \\
(\text { sec })\end{array}$ \\
\hline $\begin{array}{c}\text { Ovariectomized females after } \\
\text { treatment with oestradiol } \\
\text { benzoate and progesterone }\end{array}$ & 6 & $4 \cdot 1$ & 7.4 & 10.7 \\
$\begin{array}{c}\text { Castrated males, exposed to CA in } \\
\text { utero, after treatment with } \\
\text { oestradiol benzoate and } \\
\text { progesterone }\end{array}$ & 5 & 4.6 & 5.7 & 6.8 \\
$\begin{array}{c}\text { Untreated castrated males after } \\
\text { treatment with oestradiol } \\
\text { benzoate and progesterone }\end{array}$ & 5 & 4.6 & 4.9 & 4.6 \\
\hline
\end{tabular}

The guinea-pigs received $3 \mu \mathrm{g}$ oestradiol benzoate intramuscularly followed $36 \mathrm{hr}$ later by a subcutaneous injection of $0.2 \mathrm{mg}$ progesterone.

hand, these CA-males often showed signs of feminine sexual behaviour when in contact with normal males, although no spontaneous lordosis was observed. These findings agree with the results of tests on other species (Neumann \& Elger, 1966; Neumann, Elger \& von Berswordt-Wallrabe, 1967; Neumann, Steinbeck \& Hahn, 1970; Neumann, Elger \& Steinbeck, 1971).

The cause of the observed sexual behaviour is probably inhibition of the action of endogenous androgens by CA during the differentiation of the hypothalamic centres which influence sexual behaviour. If the androgens are inhibited in their effect during the differentiation of the hypothalamic centres, these centres become more sensitive to oestrogens when the animals are sexually

Table 2. Results of the significance calculations (from the hierarchical variance analyses)

\begin{tabular}{l|l|c}
\hline & \multicolumn{1}{c|}{ Groups compared } & Significance* \\
\hline $\begin{array}{l}\text { Occurrence of 'oestrous' behaviour } \\
\text { after treatment with oestrogen } \\
\text { and progesterone }\end{array}$ & $\begin{array}{l}\text { Group 1/Group 2+3 } \\
\text { Group 2/Group 3 } \\
\text { Between individual animals }\end{array}$ & + \\
\hline $\begin{array}{l}\text { Duration of 'oestrous' behaviour } \\
\text { after treatment with oestrogen } \\
\text { and progesterone }\end{array}$ & $\begin{array}{l}\text { Group 1/Group 2+3 } \\
\text { Group 2/Group 3 } \\
\text { Between individual animals }\end{array}$ & ++ \\
\hline $\begin{array}{l}\text { Duration of the lordosis reaction } \\
\text { after treatment with oestrogen } \\
\text { and progesterone }\end{array}$ & $\begin{array}{l}\text { Group 1/Group 2 } \\
\text { Group 2/Group 3 } \\
\text { Between individual animals }\end{array}$ & ++ \\
\hline
\end{tabular}

Group 1 = ovariectomized females treated with oestradiol benzoate and progesterone. Group $2=$ male guinea-pigs which had received prenatal treatment with cyproterone acetate, castrated and given oestradiol benzoate and progesterone. Group $3=$ castrated guinea-pigs, not given prenatal treatment, under treatment with oestradiol benzoate and progesterone.

$*-=P>0.05=$ not significant; $+=P<0.05=$ significant $;++=P<0.01=$ highly significant. 
mature. This means that if the androgenic influence is inhibited, the neural structures that influence sexual behaviour develop a feminine type of function. Consequently, treatment of castrated CA-males with oestradiol benzoate and progesterone produced a significantly longer lordosis reaction than similar treatment of castrated control males. A direct influence on the reflex behaviour does not seem likely, since Boling, Blandau, Wilson \& Young (1939) observed that the lordosis reaction can be produced manually in male and female guinea-pigs after birth. This postnatal reaction is not influenced by treatment of the mother animals with androgens during pregnancy (Goy, Phoenix \& Meidinger, 1967). Corresponding findings have been reported from studies on rats with respect to the differentiation of the centres which influence the gonadotrophin secretion (Pfeiffer, 1936; Barraclough, 1961; Neumann \& Elger, 1965; Neumann et al., 1967).

The adult CA-male guinea-pigs that were castrated and given testosterone propionate showed signs of a distinct reduction of masculine sexual behaviour, compared with that of castrated control males. This is again due to effects of the anti-androgen on the differentiation of the hypothalamic centres which are responsible for sexual behaviour, so that these are less sensitive to androgens when the animals are sexually mature.

The results of this study are not in line with the findings of Goldfoot $e t$ al. (1971) who described only a small reduction of male sexual behaviour and no behavioural feminization of the male offspring of CA-treated female guineapigs under similar conditions. We are not able to explain the differences.

\section{REFERENCES}

Avery, G. T. (1925) Notes on reproduction in guinea pigs. F. comp. Psychol. 5, 373.

Barraclough, C. A. (1961) Production of anovulatory, sterile rats by single injections of testosterone propionate. Endocrinology, 68, 62.

Boling, J. L., Blandau, R. J., Wilson, J. G. \& Young, W. G. (1939) Post-parturitional heat responses of newborn and adult guinea pigs. Data on parturition. Proc. Soc. exp. Biol. Med. 42, 128.

Dantchakoff, V. (1938a) Rôle des hormones dans la manifestation des instincts sexuels. $C$. $r$. hebd. Seanc. Acad. Sci., Paris, 206, 945.

Dantchaxoff, V. (1938b) Sur les effets de l'hormone mâle dans une jeune cobaye femelle traite depuis un stade embryonnaire (inversions sexuelles). C. r. Séanc. Soc. Biol. 127, 1255.

Goldfoot, D. A., Resko, J. A. \& Goy, R. W. (1971) Induction of target organ insensitivity to testosterone in the male guinea-pig with cyproterone. 7. Endocr. 50, 423.

Goy, R. W., Bridson, W. E. \& Young, W. C. (1961) The maximally effective period for the behavioral modification of female guinea pigs treated prenatally with testosterone propionate. Anat. Rec. 139, 232, Abstr.

Goy, R. W., Bridson, W. E. \& Young, W. C. (1964) Period of maximal susceptibility of the prenatal female guinea pig to masculinizing actions of testosterone propionate. F. comp. Physiol. 57, 166.

Goy, R. W., Phoenix, C. H. \& Meidinger, R. (1967) Postnatal development of sensitivity to estrogen and androgen in male, female and pseudohermaphroditic guinea pigs. Anat. Rec. 157, 87.

Neumann, F. \& Elger, W. (1965) Physiological and psychical intersexuality of male rats by early treatment with an antiandrogenic agent. Acta endocr., Copenh. Suppl. 100, 174.

Neumann, F. \& Elger, W. (1966) Permanent changes in gonadal function and sexual behavior as a result of early feminization of male rats by treatment with an antiandrogenic steroid. Endokrinologie, 50, 205.

Neumann, F., Elger, W. \& Steinbeck, H. (1971) Die Bedeutung der Androgene für die "Prägung des Gehirns". F. Neuro-Visceral Rel. Suppl. 10, 296.

Neumann, F., Elger, W. \& von Berswordt-Wallrabe, R. (1967) Intersexualität männlicher Feten und Hemmung androgenabhängiger Funktionen bei erwachsenen Tieren durch Testosteronblocker. Dtsch. med. Wschr. 92, 360 . 
Neumann, F., Steinbeck, H. \& Hahn, J. D. (1970) Hormones and brain differentiation. In The Hypothalamus, pp. 569-603. Academic Press, New York and London.

Preifrer, C. A. (1936) Sexual differences of the hypophyses and their determination by the gonads. Am. F. Anat. 58, 195.

Phoenix, C. H., Goy, R. W., Gerall, A. A. \& Young, W. C. (1959) Organizing action of prenatally administered testosterone propionate on the tissues mediating mating behavior in the female guinea pig. Endocrinology, 65, 369.

Young, W. C., Dempsey, E. W., Hagquist, G. W. \& Boling, J. L. (1939) Sexual behavior and sexual receptivity in the female guinea pig. 7. comp. Psychol. 27, 49.

Young, W. C., Dempsey, E. W. \& Myers, H. I. (1935) Cyclic reproductive behavior in the female guinea pig. F. comp. Psychol. 19, 313.

Young, W. C. \& GRUNT, J. A. (1951) The pattern and measurement of sexual behavior in the male guinea pig. F. comp. Physiol. Psychol. 44, 492. 